\title{
Pathobiology of transforming growth factor $\beta$ in cancer, fibrosis and immunologic disease, and therapeutic considerations
}

\author{
Gérald J Prud'homme
}

Transforming growth factor $\beta$ (TGF- $\beta$ ) is a highly pleiotropic cytokine that plays an important role in wound healing, angiogenesis, immunoregulation and cancer. The cells of the immune system produce the TGF- $\beta 1$ isoform, which exerts powerful anti-inflammatory functions, and is a master regulator of the immune response. However, this is context dependent, because TGF- $\beta$ can contribute to the differentiation of both regulatory (suppressive) T cells (Tr cells) and inflammatory Th17 cells. While TGF- $\beta$ might be underproduced in some autoimmune diseases, it is overproduced in many pathological conditions. This includes pulmonary fibrosis, glomerulosclerosis, renal interstitial fibrosis, cirrhosis, Crohn's disease, cardiomyopathy, scleroderma and chronic graft-vs-host disease. In neoplastic disease, TGF- $\beta$ suppresses the progression of early lesions, but later this effect is lost and cancer cells produce TGF- $\beta$, which then promotes metastasis. This cytokine also contributes to the formation of the tumor stroma, angiogenesis and immunosuppression. In view of this, several approaches are being studied to inhibit TGF- $\beta$ activity, including neutralizing antibodies, soluble receptors, receptor kinase antagonist drugs, antisense reagents and a number of less specific drugs such as angiotensin II antagonists and tranilast. It might be assumed that TGF- $\beta$ blockade would result in severe inflammatory disease, but this has not been the case, presumably because the neutralization is only partial. In contrast, the systemic administration of TGF- $\beta$ for therapeutic purposes is limited by toxicity and safety concerns, but local administration appears feasible, especially to promote wound healing. Immunotherapy or vaccination stimulating TGF- $\beta$ production and/or Tr differentiation might be applied to the treatment of autoimmune diseases. The benefits of new therapies targeting TGF- $\beta$ are under intense investigation.

Laboratory Investigation (2007) 87, 1077-1091; doi:10.1038/labinvest.3700669; published online 27 August 2007

KEYWORDS: transforming growth factor $\beta$; autoimmune; angiogenesis; cancer; inflammation; fibrosis

Transforming growth factor $\beta$ (TGF- $\beta$ ) is a highly pleiotropic cytokine, that in mammals exists in three isoforms (TGF- $\beta 1$, TGF- $\beta 2$ and TGF- $\beta 3) .{ }^{1-3}$ The importance of TGF- $\beta$ stems from the fact that it contributes importantly to apoptosis control, angiogenesis, wound healing, immune regulation and tumor biology. The TGF- $\beta$ s are part of a large superfamily of proteins, ${ }^{1}$ but in this review the author will focus only on the three TGF- $\beta$ isoforms. Practically all cells have receptors for the TGF- $\beta$ s, and at least one of the isoforms is produced in all tissues. ${ }^{1-3}$ The cells of the immune system produce primarily TGF- $\beta 1$. TGF- $\beta$ is also normally found in the plasma (TGF- $\beta 1$ isoform), ${ }^{1}$ and bound to extracellular matrix proteins throughout the body. ${ }^{4}$ Notably, platelets and bones contain large amounts of TGF- $\beta 1 .{ }^{1-5}$ Unlike other cytokines, it is secreted in a latent form that can be activated by various mechanisms to exert its effects. Latency is probably essential, in view of the ubiquitous expression of receptors.

The immunological functions of TGF- $\beta$ have attracted a considerable amount of attention (Figure 1). Indeed, it exerts broad anti-inflammatory and immunosuppressive effects, ${ }^{3,6}$ and complete knockout (KO) of TGF- $\beta 1$ in mice results in autoimmunity and early death from a multi-organ inflammatory syndrome. ${ }^{7,8}$ Recent studies ${ }^{3,6,9}$ have shown that it is an important differentiation factor (along with IL-2) for some regulatory $\mathrm{T}$ cells (denoted $\mathrm{Tr}$ or Treg cells) that exert powerful and diverse immunosuppressive effects. However, not all the effects of TGF- $\beta$ are suppressive because, for 


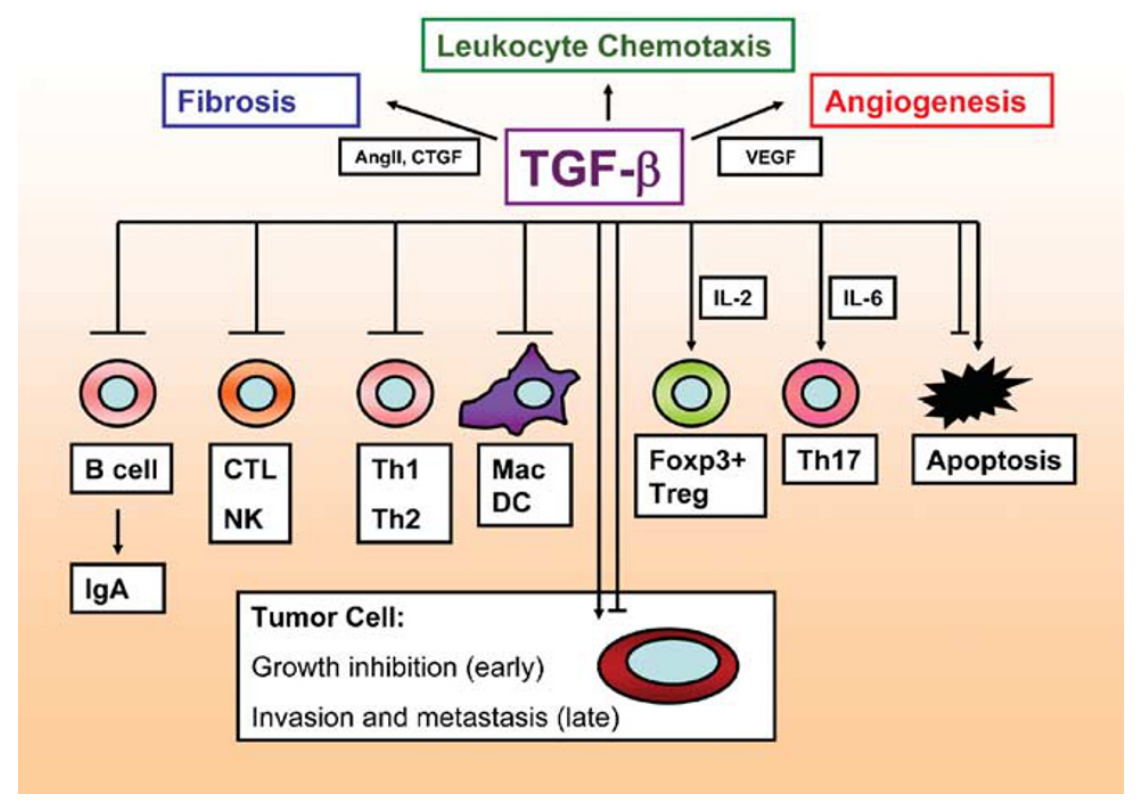

Figure 1 Pleiotropic effects of TGF- $\beta$. This cytokine (primarily the TGF- $\beta 1$ isoform) exerts multiple effects on inflammation, angiogenesis, fibrosis and tumor progression. It stimulates production of VEGF and CTGF, which contributes to angiogenesis and fibrosis, respectively. Angll stimulates production of TGF- $\beta$ and CTGF, and also promotes fibrosis. It also directly activates the Smad signaling pathway. In the early phase of tissue injury, TGF- $\beta$ exerts a strong chemotactic effect on leukocytes, but later it exerts primarily immunosuppressive effects on all arms of the immune system (Th cells, CTLs, NK cells, Mac and DCs). TGF- $\beta$ exerts a general inhibitory effect on B-cell proliferation, differentiation and antibody production, with the exception of IgA. Under optimal stimulatory conditions (where the inhibitory effects of TGF- $\beta$ are weak or absent), it promotes IgA class switching and IgA production, and contributes to mucosal immunity. In the context of T-cell activation, it promotes Foxp3 expression and regulatory T-cell differentiation (this is enhanced by IL-2). However, if the environment is rich in IL-6, differentiation to an inflammatory Th17 phenotype occurs instead. It can either promote or inhibit apoptosis, also in a context-dependent manner. TGF- $\beta$ suppresses tumor growth in the early phase of neoplasia, but promotes tumor progression (especially metastasis) at later stages. Angll, angiotensin II; CTGF, connective tissue growth factor; CTL, cytotoxic T lymphocyte; DC, dendritic cell, Mac, macrophage; NK, natural killer cell; Th, T-helper cell; Treg, regulatory T cells; VEGF, vascular endothelial growth factor.

example, in combination with IL-6 it induces the differentiation of Th17 cells, ${ }^{10}$ that have been linked to inflammation and autoimmunity. This capacity of TGF- $\beta$ to induce either immunosuppressive or inflammatory events is context dependent, and must be considered when analyzing its role in disease. ${ }^{9}$

Furthermore, TGF- $\beta$ plays a major role in cancer (as outlined below), by suppressing tumor growth in the early phase of neoplasia, while promoting tumor progression and metastasis in later phases. Thus, many malignant tumors produce large amounts of TGF- $\beta$, but are resistant to its growth inhibitory effects. At the same time, TGF- $\beta$ produced by tumors depresses anti-tumor immune responses at the level of T-helper (Th) cells, cytotoxic T lymphocytes (CTLs), dendritic cells (DCs), macrophages, natural killer (NK) cell and $\mathrm{B}$ cells, while increasing the numbers of $\operatorname{Tr}$ cells. These combined immunosuppressive effects diminish the effectiveness of cancer vaccines, and represent a major obstacle to immunotherapy.

In addition to cancer, the production of TGF- $\beta$ is altered in many pathologic conditions. This can be related to overproduction as in pulmonary fibrosis, cirrhosis, glomerulosclerosis, cardiomyopathy, Crohn's disease, scleroderma and chronic graft- $v s$-host disease (GVHD), or underproduction as in some autoimmune diseases. From this list, it is apparent that targeting TGF- $\beta$ for therapy is of major clinical interest, and the author will review the many applications and approaches that have been investigated.

\section{TGF- $\beta$ ACTIVATION AND SIGNALING}

The biology of TGF- $\beta$ is exceedingly complex, and only salient points will be mentioned. It is produced in a latent form consisting of TGF- $\beta$ and the non-covalently bound latency-associated peptide (LAP; derived from the $\mathrm{N}$-terminal of the TGF- $\beta$ precursor), that must be released for activation. ${ }^{1,2,4}$ In vitro, activation is easily accomplished by acidification, but in vivo the mechanisms are less clear and several possible modes of activation exist. ${ }^{4}$ It is thought that proteolysis by plasmin (a key component of the fibrinolytic system) and other proteases is an important mechanism. At least in some cases, plasmin-mediated activation occurs on the cell membrane. For instance, the mannose-6-phosphate/ insulin-like growth factor II receptor (M6P/IGFII-R) can bind LAP-TGF- $\beta$ on the surface of monocytes and can complex with the urokinase receptor and plasminogen to generate plasmin and activate latent TGF- $\beta .{ }^{11}$ However, other molecules such as thrombospondin 1 (TSP-1), found in platelets and the extracellular matrix, and $\alpha_{\mathrm{v}} \beta_{6}$ integrin, an 
epithelial-cell membrane protein, can also bind LAP-TGF- $\beta$ and activate it, ${ }^{12,13}$ and there is evidence that both are important. TSP- 1 is one of the few molecules that can bind both latent and active TGF- $\beta$, and it activates this cytokine by inducing a conformational change. ${ }^{14}$ Interestingly, the matrix metalloproteinases 2 and 9 (MMP-2 and MMP-9) have been implicated as activators of TGF- $\beta .^{15}$ Notably, the CD44 hyaluronan receptor provides a cell-surface receptor for proteolytically active MMP-9, which proteolytically cleaves and activates latent TGF- $\beta$. These interactions of CD44, MMPs and TGF- $\beta$ on the cell membrane appear to affect cancer cell motility, invasion and metastasis. ${ }^{16}$

It should be noted that LAP-TGF- $\beta$ is usually secreted as a large latent complex consisting of LAP-TGF- $\beta$ covalently bound to a latent TGF- $\beta$-binding protein (LTBP). ${ }^{4,17}$ At least three LTBP isoforms bind TGF- $\beta$, and it has been proposed that the LTBPs serve as structural components of the ECM and modulators of TGF- $\beta$ availability. Indeed, LTBPs target latent TGF- $\beta$ to the ECM. For instance, they concentrate TGF- $\beta$ to elastin fibrils and fibronectin-rich pericellular fibers. ${ }^{17}$ Deficiency of LTBP-4 in mice results in defective elastin structure, developmental abnormalities, emphysema and colorectal cancer. ${ }^{4,17}$

All three TGF- $\beta$ s use the same receptor and it has three components: type I (RI, or ALK5); type II (RII) and type III (RIII, or betaglycan). ${ }^{1-3,6}$ RIII binds TGF- $\beta$ (all isoforms) and recruits TGF- $\beta$ to RII, which then phosphorylates RI to form a heterotetrameric serine/threonine kinase complex. In turn, RI phosphorylates Smad2 and Smad3 (receptor-associated Smads (R-Smads)), and the latter form a heteromeric complex with Smad4, which translocates to the nucleus, binds to DNA and regulates transcription (Figure 2). Stimulation of cells with TGF- $\beta$ can result in the activation or repression of hundreds of genes. ${ }^{6}$ In contrast to these Smads, Smad7 inhibits TGF- $\beta$ signaling. TGF- $\beta$ also signals through MAPK pathways, and this can lead to a switch from tumor suppression to promotion. Indeed, several signaling molecules are activated by TGF- $\beta$ (eg, ERK, c-Jun $\mathrm{NH}_{2}$-terminal kinase (JNK), p38, PI3K, Akt and Rho-like GTPases), ${ }^{2,3}$ and there is complex cross-talk between the Smad pathway and other pathways.

In endothelial cells, ALK1 is an additional type 1 receptor, and endoglin acts as a type III-like receptor. The classic TGF$\beta /$ ALK-5 (Smad2/3) pathway inhibits endothelial cell proliferation and migration, whereas the alternative TGF- $\beta /$ ALK1 (Smad1/5) pathway has the opposite effect. ${ }^{18,19}$ The role of endoglin is not fully elucidated, but it promotes ALK1 signaling, and endothelial cells lacking endoglin do not proliferate because TGF- $\beta$ /ALK1 signaling is decreased and TGF- $\beta$ /ALK5 signaling is increased. ${ }^{19}$ Interestingly, many mutations of either the ALK1 or endoglin genes have been associated with hereditary hemorrhagic telangiectasia. ${ }^{18}$

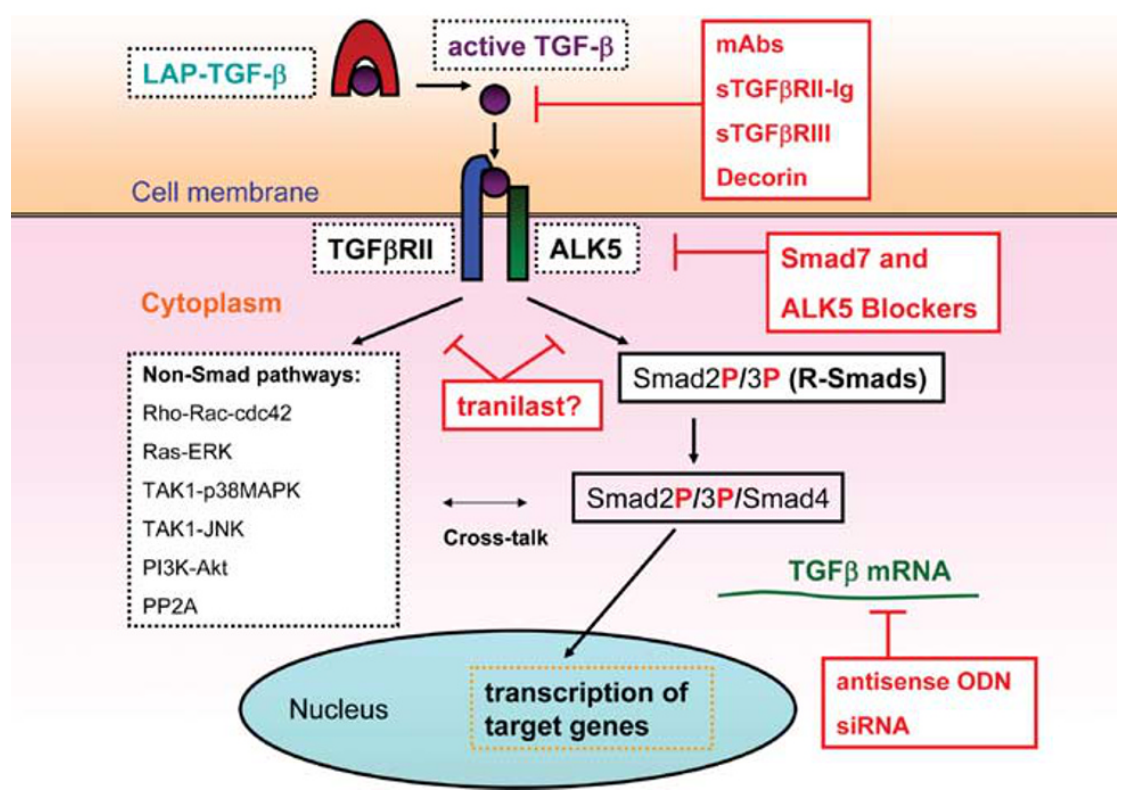

Figure 2 TGF- $\beta$ signaling and inhibition. TGF- $\beta$ must be activated by the release of LAP or a conformational change to bind to its signaling receptors. Signals are transduced through a Smad pathway and a number of non-Smad pathways, with complex cross-talk. ALK5 phosphorylates Smad2 and Smad3, which form a complex with Smad4. This complex translocates into the nucleus and (in association with other molecules) binds to DNA, and either activates or represses gene expression. In contrast, Smad7 inhibits ALK5 signaling. Therapeutically, TGF- $\beta$ activity can be reduced or blocked in many ways (denoted by red boxes), including neutralization of TGF- $\beta$ with mAbs or soluble receptors, blockage of ALK5 activity with small drugs or Smad7, prevention/ degradation of TGF- $\beta$ mRNA translation with antisense ODNs or siRNA. The mode of action of tranilast is not elucidated, but it inhibits TGF- $\beta$ production and receptor expression, and reduces signaling through both Smad and non-Smad pathways. ALK5, activin receptor-like kinase 5 (TGF- $\beta$ type I receptor); LAP, latency-associated peptide; mAbs, monoclonal antibodies; ODNs, oligodeoxynucleotides; siRNA, small inhibitory RNA; RII, type II TGF- $\beta$ receptor; TAK1, TGF- $\beta$-activated kinase 1. 
There are several non-signaling receptors of TGF- $\beta$, and some were mentioned above (M6P/IGFII-R, TSP-1, $\alpha_{\mathrm{v}} \beta_{6}$ ). Recently, we have identified neuropilin-1 (Nrp1) as a novel membrane protein that binds TGF- $\beta$ (Y Glinka, GJ Prud'homme, manuscript in preparation). Nrp1 is a multi-functional protein known as a receptor for both semaphorins and $\mathrm{VEGF}^{20}$ but it is also expressed by cells of the immune system, particularly DCs and Tr cells. ${ }^{21,22} \mathrm{Nrp}-1$ and/or its homolog Nrp2 are expressed by most cancers, and appear to contribute to their malignant phenotype. ${ }^{20}$ Remarkably, Nrp1 binds both latent and active TGF- $\beta$, and we hypothesize that it plays an important role in immunoregulation, through its ability to capture this cytokine.

In the plasma, $\alpha 2$-macroglobulin binds TGF- $\beta$ and sequesters it in an inactive form. ${ }^{23}$ This may be essential to rapidly neutralize circulating active TGF- $\beta$. Of note, TGF- $\beta$ binds to several extracellular matrix components such as TSP-1, decorin, fibronectin, elastin, some collagens and other molecules. ${ }^{4,17}$ Thus, the matrix acts as a reservoir for TGF- $\beta$ (and many other cytokines and growth factors), possibly allowing its release during pathological conditions.

\section{TGF- $\beta$ AND IMMUNE REGULATION}

TGF- $\beta$ is clearly a master regulator of the immune response, and it exerts inhibitory effects on cells of all arms of the immune system, including Th1 cells, Th2 cells, CTLs, macrophages, NK cells, B cells and polymorphonuclear leukocytes (granulocytes). These multiple effects of TGF- $\beta$ have been reviewed in the recent literature, ${ }^{3,6,9}$ and are highly relevant to autoimmune diseases. ${ }^{24}$ Importantly, it also prevents DC maturation. ${ }^{3,25}$ On the other hand, TGF- $\beta$ has potent chemoattractive properties (even at femtomolar concentrations), which can lead to the rapid accumulation of macrophages, granulocytes and other cells at the site of inflammation. ${ }^{26,27}$ The inflammatory component is amplified by the ability of TGF- $\beta$ to induce differentiation of Th17 cells. Indeed, when naïve $\mathrm{T}$ cells are activated in the combined presence of TGF- $\beta$ and IL- 6 , they differentiate into Th17 cells. ${ }^{10,28}$ However, this is highly context dependent, because Th17 differentiation is blocked by a number of cytokines such as IL-2, IL-4, IL-27 and IFN- $\gamma .^{10,28-31}$ The Th17 cells secrete large amounts of IL-17, which sustains acute inflammation by recruiting granulocytes, and also by promoting the secretion of other inflammatory cytokines. Of note, it was recently reported that, in the presence of IL-6, TGF- $\beta 1$ produced by Tr cells can contribute to Th17 differentiation and, remarkably, some $\mathrm{CD} 4{ }^{+} \mathrm{CD} 25^{+} \mathrm{Foxp}^{+} \mathrm{Tr}$ cells themselves differentiated into Th17 cells. ${ }^{32}$ It appears that TGF- $\beta$ can exert inflammatory effects early after tissue injury, but is subsequently anti-inflammatory, highlighting its bipolar nature. ${ }^{9}$ TGF- $\beta$ can also either increase or decrease apoptosis of lymphocytes, depending on their phenotype and stage of differentiation. ${ }^{3}$ In general, it promotes T-cell survival, but induces apoptosis of immature and resting B cells.
The immunosuppressive effects are most apparent on $\mathrm{T}$ cells. ${ }^{3,6}$ For instance, TGF- $\beta$ inhibits both T-cell proliferation, by targeting cell cycle regulators, and IL-2 production by blocking its transcription. The blockade of IL-2 production is highly dependent on Smad3. Other Th1 cytokines, such as IFN- $\gamma$, are also inhibited. Furthermore, TGF- $\beta$ inhibits the differentiation of Th1 cells, Th2 cells and CTLs. In CTLs and NK cells, TGF- $\beta$ is a strong antagonist of both IFN- $\gamma$ production and cytolytic activity. TGF- $\beta$ is also an important negative regulator of $\mathrm{B}$-cell proliferation and differentiation. ${ }^{33}$ Interestingly, it inhibits production of most immunoglobulin isotypes, except $\operatorname{IgA}$, which is enhanced. ${ }^{33,34}$ This promotion of IgA production corresponds to a protective role of TGF- $\beta$ in mucosal immunity.

Studies of TGF- $\beta 1 \mathrm{KO}$ mice have clearly established the important anti-inflammatory functions of this cytokine. ${ }^{7,8}$ These mice die within 3-4 weeks of birth of a multi-organ inflammatory syndrome involving the heart, skeletal muscle, lungs, liver, stomach, pancreas, brain, eyes, salivary glands and other tissues. The inflammatory infiltrate tends to be perivascular and consists of lymphocytes, macrophages and granulocytes, in varying proportion from organ to organ. There is evidence for increased leukocyte-endothelial cell interactions. ${ }^{8}$ These mice have evidence of autoimmunity, including circulating anti-dsDNA, anti-ssDNA, other antinuclear antibodies and glomerular immune complex disease. This syndrome shares features with human SLE, Sjögren's syndrome, GVHD and polymyositis. Note that these findings apply only to TGF- $\beta 1 \mathrm{KO}$ mice, while TGF- $\beta 2$ or TGF- $\beta 3$ KO mice die before or shortly after birth from developmental abnormalities. ${ }^{4,7}$ These mice have cleft palate and defective lung development and, in the case of TGF- $\beta 2$, also defects of the cardiovascular system, bones, urogenital structures and other tissues.

In the absence of TGF- $\beta 1$, there is lymphoproliferation and markedly increased numbers of activated lymphocytes in lymphoid organs, as well as an increased expression MHC class I and II molecules (which are normally downregulated by TGF- $\beta 1) .{ }^{35}$ There is also overproduction of several inflammatory cytokines, ${ }^{35}$ including MIP- $1 \alpha$, IL- $1 \beta$, TNF- $\alpha$ and IFN $-\gamma$. Anti-CD4 antibodies are protective and, similarly, autoimmune disease is diminished in TGF- $\beta 1^{-1-}$ and MHC $\mathrm{II}^{-1-}$ (double knockout) mice, ${ }^{36,37}$ demonstrating a role for Th cells. As might be expected, mice with severe combined immunodeficiency (SCID mice) are protected from this inflammatory syndrome.

In early studies, TGF- $\beta 1 \mathrm{KO}$ affected all cells and it was difficult to confirm that inflammation was dependent on a T-cell defect. However, this question has been addressed with transgenic mice expressing mutant receptors, or more limited genetic deletions. For instance, mice with a deletion of TGF$\beta$ RII restricted to T cells develop a severe autoimmune disease and die before 5 weeks of age, and are similar to complete TGF- $\beta 1^{-1-}$ mice. $^{38}$ Mice with $\mathrm{T}$ cells expressing a dominant-negative TGF- $\beta$ RII receptor have milder disease, ${ }^{3}$ 
probably because of residual receptor function. Interestingly, mice with $\mathrm{T}$ cells unable to produce TGF- $\beta 1$ (rather than a receptor defect) also have a milder disease, most likely because of production this cytokine by other cells. ${ }^{39}$

In recent years, much attention has been directed at the effects TGF- $\beta$ on Tr-cell differentiation and function. A detailed discussion of this topic is beyond the scope of this paper, but several recent reviews are available., $3,6,9,40,41$ The differentiation of natural $\operatorname{Tr}$ cells (nTr cells) of $\mathrm{CD} 4{ }^{+} \mathrm{CD} 25^{+} \mathrm{Foxp}^{+}{ }^{+}$phenotype in the thymus appears to be TGF- $\beta$ independent. In contrast, the differentiation of induced (adaptive) Tr cells (iTr cells) in the periphery is highly TGF- $\beta$ dependent. Indeed, TGF- $\beta$ induces the differentiation of Foxp $3^{+}$Tr cells from either antigen- or CD3mAb-stimulated $\mathrm{CD} 4{ }^{+} \mathrm{CD} 25^{-} \mathrm{Foxp}^{-}$precursors, and this effect is greatly enhanced by IL-2. ${ }^{42}$ Furthermore, in the periphery, TGF- $\beta$ appears essential for the maintenance of Foxp3 expression, regulatory function and homeostasis of both $n \operatorname{Tr}$ and $i \operatorname{Tr}$ cells. ${ }^{41,43-45}$ The process of naive T-cell differentiation to the Foxp $3^{+}$iTr phenotype requires both T-cell receptor (TCR) signaling and TGF- $\beta$ stimulation, and the persistence of this phenotype is dependent on TGF- $\beta{ }^{45}$ Indeed, in the case of $i \operatorname{Tr}$ cells removal of TGF- $\beta$ results in Foxp3 loss in vitro; and after adoptive transfer of these cells it is also downregulated rapidly in vivo (2 days), except for a small residual population. ${ }^{45}$ This loss of Foxp3 expression is much less in nTr cells. There is also evidence that the cytokine profiles of $i \operatorname{Tr}$ and $n \operatorname{Tr}$ cells are rather similar, showing low IL-2, IL-4, IL-5, IFN- $\gamma$ and TNF- $\alpha$ production, but high IL-10 production. ${ }^{45}$

A separate and more controversial issue is whether TGF- $\beta$ contributes to the suppressive activity of $\operatorname{Tr}$ cells. In the case of $n T r$ cells, suppression appears to be dependent on direct cell contact, and has been observed (at least in vitro) in the complete absence of TGF- $\beta .^{41}$ The issue of contact dependence, however, does not exclude a role for TGF- $\beta$, because LAP-TGF- $\beta$ has been reported on the membrane of both $\mathrm{nTr}$ and iTr cells, and might suppress through a contact-dependent mechanism. ${ }^{46}$ Effector $\mathrm{T}$ cells engineered to be unresponsive to TGF- $\beta$ (dominant-negative RII) are resistant to the suppressive activity of $\mathrm{Tr}$ cells. ${ }^{47}$ Furthermore, the results of some in vivo studies, including a recent one with TGF$\beta$-null T cells, ${ }^{39}$ reveal an important role for TGF- $\beta$ as an effector molecule of Foxp $3^{+} \operatorname{Tr}$ cells. Indeed, TGF- $\beta$ was required to inhibit both Th1 differentiation and inflammatory bowel disease.

It seems likely that $\operatorname{Tr}$ cells can suppress by more than one mechanism, depending on the type of immune response or inflammation that is occurring. It is important to add that Th3 cells, which contribute to some forms of immune tolerance (especially when orally induced), produce TGF- $\beta$ which appears to be their main mode of suppressive action. ${ }^{48,49}$ In addition, $\mathrm{Tr} 1$ regulatory $\mathrm{T}$ cells, ${ }^{50}$ which are particularly relevant to the control of inflammatory bowel disease, secrete IL-10 and TGF- $\beta$, which both exert important regulatory effects.

\section{TGF- $\beta$ IN HEALING AND FIBROSIS}

Wound repair is a complex multi-phase process, involving inflammatory cell chemotaxis, fibroblast proliferation, collagen and matrix deposition, angiogenesis, reduced matrix degradation by metalloproteinases, remodeling and, in the skin, re-epithelialization. ${ }^{51-53}$ Early on, fibroblasts and endothelial cells migrate to the wound site, where they form highly vascular granulation tissue. Fibroblasts in granulation tissue transform into myofibroblasts, and eventually the lesion evolves into a scar with dense collagen, and much reduced vascularity and cellularity. In hypertrophic scars and other pathological fibrosis, there is retention of a high number of fibroblasts and myofibroblasts, and an abundant immature collagen matrix.

TGF- $\beta$ stimulates most of the processes of wound healing (in collaboration with many other growth factors), and is a major profibrotic factor. ${ }^{4,53-56}$ Connective tissue growth factor (CTGF), which is induced by TGF- $\beta$, is a major contributor to this process. ${ }^{53-55}$ TGF- $\beta$ also induces endothelin1 , and TGF- $\beta$ /endothelin- 1 interactions may play a role in the development of fibrosis in scleroderma ${ }^{55}$ and myocardial disease. ${ }^{54}$ When TGF- $\beta$ is overproduced there is excessive collagen and matrix deposition, culminating in organ dysfunction or failure. Inflammation, ischemia, radiation and toxins are all initiation factors for fibrogenesis, and it can adversely affect the lungs, heart, liver, kidneys and other organs and tissues. This has been demonstrated, for example, by TGF- $\beta$ gene transfer into the lung, ${ }^{57}$ and in bleomycininduced pulmonary fibrosis. ${ }^{56}$ Indeed, cancer chemotherapy with bleomycin results in TGF- $\beta$ production in the lung, and subsequent pulmonary fibrosis, which is a major adverse effect. The Smads are involved, and Smad3-null mice resist TGF- $\beta$-induced pulmonary fibrosis. ${ }^{57}$ The importance of fibrosis in human disease cannot be understated, and it responds poorly (if at all) to current therapies.

\section{TGF- $\beta$ IN CANCER: TUMOR SUPPRESSION VS PROMOTION}

As mentioned previously, TGF- $\beta$ can act as either a tumor suppressor or a tumor promoter. ${ }^{5-64}$ Suppression of tumor cell growth by TGF- $\beta$ depends on its ability to upregulate cyclin kinase inhibitors. However, as pre-malignant lesions progress they become refractory to growth inhibition, and begin to produce large amounts of TGF- $\beta$. Many malignant tumors have mutated or downregulated TGF- $\beta$ RII receptor, or other abnormalities of the TGF- $\beta$ signaling pathways. ${ }^{65}$ TGF- $\beta$ RIII (betaglycan) loss or downregulation has also been linked to breast cancer progression. ${ }^{66}$

With tumor progression, TGF- $\beta$ becomes a tumor promoter and induces epithelial-to-mesenchymal transition (EMT) by Smad-dependent and -independent pathways. ${ }^{67-69}$ EMT is associated with increased secretion of MMPs, which promote tumor intravasation or extravasation. The effects of TGF- $\beta$ on EMT, tumor growth or metastasis can be dissociated, and might be dependent on different signaling 
pathways. ${ }^{68,69}$ Interestingly, a mutated TGF- $\beta$ type I receptor unable to bind Smad2/3, but with a functional kinase domain (capable of activating MAPK and other pathways) showed that deficient $S \operatorname{mad} 2 / 3$ signaling increased the malignancy of a well-differentiated xenografted tumor cell line (higher proliferative index and more malignant histologic features), but suppressed formation of lung metastases by a more aggressive variant of this cell line. ${ }^{60}$ This suggests a dominant role for Smad2/3 signaling pathway in both the tumor suppressor and prometastatic activities of TGF- $\beta$. These authors also reported that non-Smad signaling pathways, including p38 and JNK, cooperated with TGF- $\beta /$ Smads in enhancing the migration of metastatic cells, but the non-Smad pathways were not sufficient for inducing metastasis. At any rate, tumor cells respond aberrantly to TGF- $\beta$, but TGF- $\beta$ signaling appears to be required for both invasiveness and metastasis in late-stage tumorigenesis. ${ }^{70}$ Furthermore, TGF- $\beta$ plays an important role as a mediator of interactions between stromal cells and tumor cells, and it regulates the tumor microenvironment. ${ }^{65}$

A recent study in a transgenic murine model of breast cancer revealed that radiotherapy or chemotherapy with doxorubicin increased systemic levels of TGF- $\beta 1$, and circulating tumor cells and lung metastases. ${ }^{71}$ These negative effects of cancer therapy were reversed by the administration of a neutralizing anti-TGF- $\beta$ mAb (2G7). It has been known since the early 1990s that anti-TGF- $\beta$ antibodies are protective against experimental breast carcinoma. The intraperitoneal (i.p.) injection of $2 \mathrm{G} 7 \mathrm{mAb}$ (like $1 \mathrm{D} 11$ it neutralizes the TGF- $\beta 1,2,3$ isoforms) in nude mice reduced the i.p. tumor growth and lung metastases from i.p. injected MDA-231 human breast cancer cells. ${ }^{72}$ 2G7 Therapy was associated with increased NK cell activity, and these cells were required for the antitumor effect. The impact of overexpressed TGF- $\beta$ or activated Smad pathways in the development of a malignant tumor phenotype or metastatic disease has been demonstrated in several transgenic models. ${ }^{73}$ In contrast, TGF- $\beta$ blockade can be protective. ${ }^{73}$ However, in an experimental models of mouse mammary carcinoma, conditional KO of TGF- $\beta$ RII in mammary epithelial cells reduced tumor latency and increased lung metastases, ${ }^{59}$ presumably because of the loss of TGF- $\beta$ 's tumor suppressor effect at the earliest stages of disease. These studies suggest that inhibiting TGF- $\beta$ might not be beneficial in patients genetically predisposed to cancer (since it would remove a tumor suppressor effect), but could ameliorate disease in patients who present with existing TGF- $\beta$-producing cancers. TGF- $\beta$ is produced by a wide variety of tumors (of breast, lung, GI tract, pancreas, ovary, CNS, skin/melanoma and other). ${ }^{61-65,74}$ Interestingly, elevated TGF- $\beta 1$ plasma levels are frequently observed in cancer patients, and this generally correlates with a poor prognosis, ${ }^{75-79}$ although these levels are notoriously difficult to measure due to partial platelet degranulation (platelets contain large amounts of TGF- $\beta 1)$.
Importantly, TGF- $\beta$ stimulates production of CTGF, endothelin-1 and VEGF, ${ }^{53-55,80,81}$ and all these factors collaborate in promoting the formation of a vascular and fibrous tumor stroma. Moreover, TGF- $\beta$ attracts macrophages and other inflammatory cells to the stroma, and these cells secrete various mediators and growth factors that sustain tumor progression. ${ }^{65}$ Some of these infiltrating leukocytes differentiate into myeloid suppressor cells, which have broad immunosuppressive properties. ${ }^{82}$ TGF- $\beta$ (produced by either tumor or stromal cells) also directly exerts a wide spectrum of immunosuppressive effects, and induces the differentiation of $\operatorname{Tr}$ cells, markedly limiting antitumor immunity. TGF- $\beta$ inhibits DC functions and interferes with immunization with DC-based vaccines. ${ }^{83}$ In accord with the suppressive role of TGF- $\beta$, effector $\mathrm{CD} 8^{+} \mathrm{T}$ cells expressing a dominant-negative TGF- $\beta$ RII are more effective at eliminating tumors. ${ }^{84}$

One of the most clinically relevant aspects of TGF- $\beta$ in cancer is its ability to promote bone metastasis. ${ }^{85-91}$ This is particularly relevant to breast carcinoma, where bone metastases give rise to debilitating disease. This feature can be targeted for cancer therapy. For instance, in a human breast cancer xenograft model (in nude mice), an ALK5 inhibitor reduced the incidence of both lung and bone metastases. ${ }^{90}$ In breast carcinoma, TGF- $\beta$ acts (at least in part) by stimulating the production of parathyroid hormone-related protein (PTHrP), ${ }^{86,87,91}$ which stimulates bone resorption by osteoclasts and the formation of osteolytic bone metastases. The stimulation of PTHrP is dependent on both the Smad and the p38 MAPK pathways of TGF- $\beta$ signaling. ${ }^{91}$ TGF- $\beta$ is stored in the bone matrix and can be released during osteolysis. Other mediators such as IL-8, CTGF, chemokine receptor CXCR4, IL-11, MMPs and osteopontin have been implicated in the formation of bone metastases. ${ }^{88}$ Since TGF- $\beta$ can upregulate production of CTGF, IL-11 and MMPs, these factors are likely to interact in the metastatic process. CD44 also appears to be important. It binds to matrix hyaluronan and has various tumor promoting activities and, as noted previously, might contribute to the activation of TGF- $\beta .^{16}$

\section{THE INHIBITION OF TGF- $\beta$ ACTIVITY FOR THERAPEUTIC PURPOSES}

Several large- and small-molecule drugs inhibiting TGF- $\beta$ are being tested in preclinical and clinical trial (ranging from phase I to III) (Table 1). There have been several reviews of these drugs in the treatment of various conditions, ${ }^{73,74,92-103}$ and the author will discuss more extensively some agents that have received less attention, such as tranilast and angiotensin II (AngII) blockers. The therapeutic agents being most studied include mAbs, soluble TGF- $\beta$ receptors, antisense oligonucleotides (ODNs) and inhibitors of ALK5 (TGF- $\beta$ RI) (Tables 1 and 2; Figure 2). These TGF- $\beta$ inhibitory drugs are currently being developed primarily to treat either fibrotic disease or cancer, and some salient findings are summarized in Table 1, although this list is not complete and reviews 
Table 1 Examples of drug-mediated specific inhibition of TGF- $\beta$

\begin{tabular}{|c|c|c|c|}
\hline mAbs (pan-TGF- $\beta$; TGF- $\beta 2$ or TGF- $\beta 2,3$ ) & $\begin{array}{l}\text { Fibrosis } \\
\text { Renal disease } \\
\text { Cancer } \\
\text { Heart disease } \\
\text { Radiation injury }\end{array}$ & $\begin{array}{l}\text { Preclinical and clinical phases I-III. Preclinical } \\
\text { studies (eg, with mouse1D11 or } 2 \mathrm{G} 7 \mathrm{mAb} \text { ) } \\
\text { show positive effects in rodent fibrosis, renal } \\
\text { disease, cancer and other, but reveal some } \\
\text { adverse effects at high doses (see text) }\end{array}$ & $71-73,92,94,96,100,104$ \\
\hline $\begin{array}{l}\text { Soluble TGF- } \beta \text { RII receptor constructs (with or } \\
\text { without Ig fusion) Target TGF- } \beta 1 \text {, 3. Protein or } \\
\text { gene therapy }\end{array}$ & Cancer & $\begin{array}{l}\text { Preclinical. Effective in cancer models (pancreas, } \\
\text { colon, lymphoma, other). Few adverse effects in } \\
\text { transgenic mice, and reduced mammary tumor } \\
\text { metastases }\end{array}$ & $96,98,100,105$ \\
\hline $\begin{array}{l}\text { Soluble TGF- } \beta \text { RIII, or P144 peptide. Targets } \\
\text { TGF- } \beta(\beta 2>\beta 3>\beta 1)\end{array}$ & $\begin{array}{l}\text { Cancer } \\
\text { Fibrosis }\end{array}$ & $\begin{array}{l}\text { Preclinical. Effective against human breast } \\
\text { cancer xenografts (MDA-MB-231) in nude mice }\end{array}$ & $66,106-108$ \\
\hline $\begin{array}{l}\text { Nucleic acid-based therapies (antisense ODNs, } \\
\text { ribozymes, siRNA, Smad7) }\end{array}$ & Cancer & $\begin{array}{l}\text { Antisense ODNs are at an advanced stage of } \\
\text { clinical development for high-grade gliomas. } \\
\text { Other agents are at a preclinical stage. Delivery } \\
\text { of these agents is challenging }\end{array}$ & $92,96,97,100,101$ \\
\hline $\begin{array}{l}\text { ALK5 inhibitors (GW6604, Ly580276, Ly2157299, } \\
\text { SB-505124, SB- 431542, SD-208, several others) }\end{array}$ & $\begin{array}{l}\text { Fibrosis } \\
\text { Cancer }\end{array}$ & $\begin{array}{l}\text { Preclinical or phase I. Advantage of orally active } \\
\text { small drugs. Have incomplete specificity for } \\
\text { ALK5. Predominantly tested in fibrosis models. } \\
\text { Can block breast cancer metastasis }\end{array}$ & $73,90,92,94-97,109$ \\
\hline
\end{tabular}

ALK5, activin receptor-like kinase 5 (alternative name for the TGF- $\beta$ type I receptor); mAbs, monoclonal antibodies; ODN, oligodeoxynucleotides; P144, peptide derived from the TGF- $\beta$ RIII sequence (inhibits TGF- $\beta$ ); RII, type II TGF- $\beta$ receptor; RIII, type III TGF- $\beta$ receptor; siRNA, small inhibitory RNA; TGF- $\beta$, transforming growth factor $\beta$.

containing additional information are quoted. At least a dozen ALK5 inhibitors are being developed by pharmaceutical companies. They have the advantage of being small drugs that can be administered orally, and have shown effectiveness in preclinical models against pulmonary fibrosis, other fibrotic diseases and various malignant tumors. It is interesting that an ALK5 inhibitor was able to ameliorate both early acute fibrogenesis and established fibrosis in a TGF- $\beta$-induced model of pulmonary fibrosis. ${ }^{109}$ Despite some highly encouraging results, none of the drugs listed in Table 1 is yet approved for regular clinical use.

However, some drugs commonly used to treat other diseases can inhibit TGF- $\beta$ production and/or action (Table 2). This includes antihypertensive drugs that block the reninangiotensin-aldosterone (RAS) system. This relates to the fact that AngII stimulates TGF- $\beta$ production in the kidney and elsewhere. ${ }^{53,100,147,148}$ Another important inhibitor of TGF- $\beta$ is the antiallergic/antifibrotic drug tranilast, used clinically in Japan for many years. These less specific agents may have some therapeutic advantages, at least in some diseases, because they target other aspects of the pathological process and are generally of low toxicity. Furthermore, in the case of cancer, there is a growing realization that drugs that act on a single molecular target may be less effective than those that have multiple targets, because tumor cells mutate rapidly.

\section{ADVERSE EFFECTS OF TGF- $\beta$ INHIBITION}

In view of the many biological effects of TGF- $\beta$, including its anti-inflammatory activity, it might be assumed that its inhibition would be highly detrimental. However, contrary to expectations, severe toxicity has not been observed when TGF- $\beta$ was inhibited by a variety of agents in adult rodents or humans. This paucity of adverse effects undoubtedly results from incomplete inhibition of TGF- $\beta$ activity, because null mutations in mice, as noted previously, produce a rapidly fatal inflammatory syndrome. Ruzek et $a l^{104}$ observed only minimal pathologic alterations in 
Table 2 Examples of multi-action drugs that inhibit TGF- $\beta$

\begin{tabular}{|c|c|c|c|}
\hline Drug & Disease relevance & Stage/observations & References \\
\hline \multirow[t]{9}{*}{ Tranilast } & Allergy & In clinical use for allergy and fibrotic disease in & $103,110-146$ \\
\hline & Fibrosis & Japan. Inhibits TGF- $\beta$, VEGF, PGE2 and several & \\
\hline & Autoimmunity & cytokines. Exerts antiproliferative, anticancer & \\
\hline & Renal & and immunosuppressive effects. Low toxicity & \\
\hline & disease & & \\
\hline & Cardiomyopathy & & \\
\hline & Diabetic complications & & \\
\hline & Crohn's disease & & \\
\hline & Cancer & & \\
\hline \multirow{8}{*}{$\begin{array}{l}\text { Inhibitors of renin-angiotensin system (ACE } \\
\text { inhibitors; AT1 receptor blockers) }\end{array}$} & Hypertension & Commonly prescribed antihypertensive drugs, & $53,139,147-153$ \\
\hline & Renal disease & with few adverse effects. Block Angll induction & \\
\hline & Congestive heart failure & of TGF- $\beta$ and decrease TGF- $\beta$ levels & \\
\hline & Pulmonary fibrosis & & \\
\hline & Cirrhosis & & \\
\hline & Scleroderma & & \\
\hline & Muscular dystrophy & & \\
\hline & Cancer & & \\
\hline \multirow[t]{5}{*}{ HMG CoA reductase inhibitors (statins) } & Hypercholesterolemia & Commonly prescribed cholesterol-lowering & $99,154-157$ \\
\hline & Cardiomyopathy & drugs, with few adverse effects. Statins inhibit & \\
\hline & Fibrosis & the effects of TGF- $\beta$ on CTGF induction and fi- & \\
\hline & Renal disease & broblast collagen synthesis & \\
\hline & Diabetes & & \\
\hline \multirow[t]{5}{*}{ Pirfenidone } & Fibrosis & This antifibrotic drug has been shown to inhibit & $100,158,159$ \\
\hline & Neurofibromatosis & TGF- $\beta$ production. It has been reported to exert & \\
\hline & Cancer & anticancer and anti-inflammatory effects. It may & \\
\hline & Asthma & be of benefit in pulmonary fibrosis, asthma and & \\
\hline & Multiple sclerosis & multiple sclerosis & \\
\hline
\end{tabular}

ACE, angiotensin-converting enzyme; Angll, angiotensin II; AT1, angiotensin II type 1 receptor; CTGF, connective tissue growth factor; HMG CoA, 3-hydroxy-3methylglutaryl-coenzyme A; PGE2, prostaglandin E2; TGF- $\beta$, transforming growth factor $\beta$; VEGF, vascular endothelial growth factor.

major organs or tissues, or in lymphocyte numbers and function, in mice chronically treated with an anti-TGF- $\beta$ $\mathrm{mAb}$ (1D11) that neutralizes all three isoforms. Doses of up to $50 \mathrm{mg} / \mathrm{kg}$ three times a week (resulting in blood levels of $1-2 \mathrm{mg} / \mathrm{ml}$ ) for 12 weeks were investigated. Similarly, transgenic mice expressing a soluble TGF- $\beta$ RII-Fc fusion protein that neutralizes TGF- $\beta 1$ and TGF- $\beta 3$ did not develop severe pathology and usually had only mild inflammatory lesions, despite lifetime exposure to that protein. ${ }^{105}$ There was also no increase in spontaneous tumorigenesis. Nevertheless, some pathological consequences have been noted in other studies, especially when TGF- $\beta$ inhibitory agents are applied at high doses. Thus, although 1D11 antibody administration was well tolerated at low therapeutic doses, at high doses it induced epithelial hyperplasia of the tongue in mice, associated with dysphagia and weight loss, and increased progression to carcinoma in a model of familial adenomatous polyposis (data presented by Scott Lonning, Genzyme Corporation, at TGF- $\beta$ in Cancer and Other Diseases conference, La Jolla, CA, 2006). In this respect, it is of some concern that TGF- $\beta$ blockade accelerates the progression of tumors in some genetically determined cancer models. ${ }^{59}$ Evidently, the incidence of tumors in patients treated with TGF- $\beta$ inhibitors should be closely monitored. In addition, inhibition of ALK5 signaling has been reported to induce physeal dysplasia in rats. ${ }^{160}$ Undoubtedly, other adverse effects will occur, and the consequences of very long-term treatment in humans are not known, and TGF- $\beta$ blockade might become pathogenic above a certain threshold. 


\section{DRUGS WITH MULTIPLE ACTIONS THAT INHIBIT TGF- $\beta$} Tranilast ( $\mathrm{N}$-[3,4-Dimethoxycinnamoyl]Anthranilic Acid)

This drug was developed by Kissei Pharma (Japan) and has been studied in several thousand patients for various indications. ${ }^{110}$ It blocks mast cell degranulation and has been used clinically in Japan and South Korea for the treatment of allergic disorders (asthma, allergic rhinitis and atopic dermatitis). ${ }^{110-114}$ In addition, it has potent antifibrotic effects, ${ }^{110,115-117}$ and has been successfully used for the treatment of hypertrophic scars and keloids. It might also find applications in renal disease and myocardial fibrosis. ${ }^{111}$ Importantly, many years of clinical use have revealed that it is safe and well tolerated by most patients at doses of up to $600 \mathrm{mg} /$ day for months. ${ }^{110}$ Obviously, this represents a major advantage over other drugs that are in the early or mid-phase of development. In animals, the antifibrotic effects of tranilast have been demonstrated extensively in various disease models. ${ }^{111,118-125}$ They are also apparent in a newly described in vitro model of fibrosis, designed for screening antifibrotic drugs. ${ }^{126}$

The mechanisms of tranilast's antifibrotic effects are not fully understood, but a major effect is the inhibition of both TGF- $\beta$ expression and action. ${ }^{115,123-139}$ In cell culture assays, tranilast inhibited both TGF- $\beta$ secretion and TGF- $\beta$ receptor expression. ${ }^{12,129}$ Furthermore, it inhibited phosphorylation of Smad $2^{125}$ and ERK, ${ }^{131}$ suggesting that it impedes both Smad-dependent and -independent TGF- $\beta$ signaling pathways. Gilbert and co-workers ${ }^{125,133,136}$ examined the effects of tranilast on TGF- $\beta$-induced matrix synthesis, and found that it was suppressed both in vitro and in vivo. These investigators assessed TGF- $\beta$ expression in target tissues, as wells as Smad phosphorylation, by examining the expression of phosphorylated Smad2 with an mAb that detects only the phosphorylated form. Their studies showed dramatic attenuation of both molecules with tranilast treatment.

However, this inhibitory effect is not specific, as tranilast also inhibits the production of other cytokines, including IL-6, IL-12, IFN- $\gamma$, and monocyte chemoattractant protein$1 .^{123,132,140,141}$ As such, it exerts at least mild immunosuppressive effects. For instance, we recently found that it inhibits production of IL-17 by lymphocytes and tumor cells (unpublished observations). This cytokine has been linked to both autoimmunity and tumor progression. ${ }^{10}$ Interestingly, tranilast was protective against experimental autoimmune encephalomyelitis (EAE), ${ }^{140}$ where IL-17 is thought to play an important pathogenic role. In addition, tranilast strongly inhibits PGE2 production ${ }^{132}$ and antagonizes the effects of VEGF; ${ }^{142}$ two mediators that are involved in immunity, wound healing and cancer progression.

In recent years, on the basis of successful preclinical studies, tranilast was investigated for the prevention of restenosis after percutaneous transluminal coronary revascularization (PRESTO clinical trial), but was not found effective in that application. However, there is early evidence that it might be effective against intestinal stricture progres- sion in Crohn's disease ${ }^{143}$ (which is partly TGF- $\beta$ dependent). If confirmed, this would be of considerable interest because more specific inhibitory drugs, such as ALK5 blockers, might enhance the inflammatory component of the disease by removing TGF- $\beta$ 's suppressive effect. In contrast, tranilast appears to be able to inhibit TGF- $\beta$ while maintaining an immunosuppressed environment, presumably through the co-inhibition of inflammatory mediators.

Tranilast has notable antitumor effects, but the mechanisms are not fully understood and might involve several factors. In vitro, it exerts antiproliferative effects on fibroblasts, vascular smooth muscle cells, lymphocytes and tumor cells $^{131,140,144-146,161}$ (our unpublished observations). It inhibits the proliferation of uterine leiomyoma cells in vitro through G1 arrest associated with the induction of the cyclindependent kinase inhibitor p21 and the tumor suppressor p53. ${ }^{145,146}$ In addition, as noted above, it inhibits PGE2 and VEGF effects that are relevant to tumor progression.

In tumor cell cultures of various origins (eg, breast, stomach, lung, pancreas, CNS/glioma) it inhibited TGF- $\beta$ (all isoforms examined) and antagonized TGF- $\beta$-mediated effects on cell migration and proliferation at non-cytotoxic concentrations. In vivo, it inhibited the growth of 9L glioma cells and reduced the expression of TGF- $\beta 2 .{ }^{131}$ The proliferation of the human schirrhous gastric cancer cell line OCUM-2M was inhibited in vivo by tranilast alone, or in combination with cisplatin. ${ }^{162}$ Interestingly, the invasive ability of OCUM2D cells was significantly increased by co-culturing with fibroblasts (NF-10 cells), which produce TGF- $\beta 1$ and this effect was countered by tranilast. ${ }^{134}$ Other investigators ${ }^{163}$ reported that tranilast inhibited growth and lymph-node metastasis of the OSC-19 human squamous cell carcinoma cell line in nude mice. Fibrous tissue, microvessel density, and the PCNA labeling (proliferative) index of the tumors were significantly reduced. Similarly, tranilast exerted antitumor and antiangiogenic effects in a murine Lewis lung carcinoma model, and it potentiated the effects of cyclophosphamide, adriamycin and other anticancer drugs. ${ }^{164}$

\section{INHIBITORS OF ANGII ACTIVITY}

There are multiple interactions between the RAS and TGF- $\beta$ pathways, some of which can be blocked with antihypertensive drugs. ${ }^{53,147-149}$ Indeed, AngII increases TGF- $\beta$ production by some cell types in the kidney, cardiovascular system and other tissues. It also enhances the expression of the TGF- $\beta$ receptors through the MAPK pathway. ${ }^{165}$ Moreover, AngII can activate the Smad signaling pathway independently of TGF- $\beta .^{53}$ Both AngII and TGF- $\beta$ increase release of CTGF. As a result, increased levels of AngII, as in many diseases, can lead to fibrosis and various TGF- $\beta$-related pathology. In this respect, it should be noted that TGF- $\beta$ participates in several cardiovascular conditions including healing myocardial infarcts (MIs), coronary artery restenosis, cardiac hypertrophy, hypertrophic and dilated cardiomyopathies, and hypertension. It also has a complex role in 
atherosclerosis, which is still being elucidated. Similarly, TGF- $\beta$ can be linked to many renal diseases, where there is either glomerulopathy or interstitial fibrosis.

Drugs that inhibit the RAS include angiotensin-converting enzyme (ACE) inhibitors and antagonists of the AngII type 1 receptor (AT1). They are safe drugs commonly used to treat hypertension, but clearly have activities beyond their antihypertensive effects, including inhibition of TGF- $\beta$. For instance, Losartan, an AngII receptor blocker, reduced TGF- $\beta$ production and ameliorated disease in a rat model of bleomycin-induced pulmonary fibrosis. ${ }^{150}$ Similarly, it inhibited TGF- $\beta$ production in mice with either fibrilin-1 or dystrophin deficiency, and this improved muscle regeneration in these disease models. ${ }^{151}$ Interestingly, some investigators have shown that high glucose levels stimulate TSP-1-dependent TGF- $\beta$ activation in glomerular mesangial cells. ${ }^{152}$ TSP- 1 , as mentioned previously, activates latent TGF- $\beta$. They found that AngII also upregulated TSP-1 production and TSP-1dependent TGF- $\beta$ activation by mesangial cells and, furthermore, that rat cardiac fibroblasts responded similarly. These AngII effects were blocked by Losartan. The glucose and AngII stimulation of TGF- $\beta$ activation appear to be synergistic, and this is clearly relevant to both diabetes and hypertension.

In the remnant kidney model, characterized by renal TGF$\beta$ production and associated glomerulosclerosis and interstitial fibrosis, both tranilast and the ACE inhibitor perindopril were protective. ${ }^{139}$ Both drugs were capable of inhibiting TGF- $\beta$ activity as manifested by reduced nuclear phosphorylated Smad2. The combination of the two drugs was more effective than either alone, and perindopril provided the additional benefit of blood pressure reduction. Of note, the ACE inhibitor was at least as effective as tranilast in suppressing the TGF- $\beta$ response. However, from the current literature, it does not appear that inhibitors of the RAS system are as effective as tranilast in mediating antiinflammatory, antiproliferative and anticancer effects.

Clinically, treatment with ACE inhibitors or AngII receptor antagonists appears to alleviate TGF- $\beta$-dependent pathology in several renal and cardiovascular diseases. ${ }^{53,149}$ It seems likely that they would also be of benefit in cirrhosis and other diseases characterized by fibrosis. In view of their favorable safety profile, they might be appropriate agents to treat these conditions. However, at least in renal disease, recent studies suggest that these drugs are more effective in rodent disease models than in humans. ${ }^{153}$ Interestingly, statins have antifibrotic and anti-inflammatory activity, and may interfere with some TGF- $\beta$-mediated effects (Table 2). However, the mechanism of action and clinical significance of statins in the context of TGF- $\beta$-induced disease have not been extensively characterized.

\section{TGF- $\beta$ DELIVERY FOR THERAPEUTIC PURPOSES}

In the previous sections the author has concentrated mostly on the negative effects of TGF- $\beta$, but this cytokine has several positive effects that might also be amenable to therapy. This includes autoimmune diseases, as we have previously reviewed, ${ }^{24,166}$ wound healing and cardiac remodeling after ischemic injury.

In preclinical models of autoimmune disease, we and others found that TGF- $\beta$ gene therapy, or in some cases protein therapy, is beneficial in autoimmune (type 1) diabetes (T1D), EAE, inflammatory bowel disease and various types of arthritis. ${ }^{24,166}$ It should be noted that both active and latent TGF- $\beta$ were effective but, in the case of protein therapy, relatively large amounts had to be administered. The use of gene therapy approaches, such as intramuscular delivery of expression plasmids, or administration of various viral vectors, allows relatively long-term expression of the cytokine at therapeutic levels. ${ }^{166}$ Gene transfer with plasmids is greatly improved by in vivo electroporation and raises fewer safety concerns than viral therapy, ${ }^{167}$ but these gene therapeutic approaches are not approved for clinical use. Furthermore, there are a number of obstacles to systemic TGF- $\beta$ therapy, and its pleiotropic effects raise many safety issues. In animals, consistent with the known activities of TGF- $\beta 1$, chronic administration (or transgenic overexpression) has led to interstitial fibrosis, glomerulosclerosis, hepatic fibrosis, cardiac disease and lesions in several other target tissues. ${ }^{1,168}$ Another caveat, at least in the area of autoimmune diseases, is the recent realization that, in conjunction with IL-6, TGF- $\beta$ promotes the differentiation of inflammatory Th17 cells. This is highly context dependent (influenced by many cytokines), and either beneficial or detrimental effects might be observed depending on the type of autoimmune disease, or the stage of disease at the time of treatment.

In clinical trials, systemic therapy has been associated with nephrotoxicity, anemia and other adverse effects (reviewed in Flanders and Roberts ${ }^{1}$ ). For this reason, TGF- $\beta$ therapy was abandoned by most pharmaceutical companies before the year 2000. Indeed, toxicity and pleiotropic effects are a general limitation of therapy with other cytokines as well. In view of this, local therapies appear more promising, and the ability of TGF- $\beta$ to promote healing is of great interest. For instance, in preclinical trials of diabetic wound healing, this has been achieved by local electroporation-enhanced TGF- $\beta$ gene transfer. ${ }^{169}$ Whether these gene therapy approaches can be transferred to the clinic remains to be determined. As a caveat, a clinical trial of topical TGF- $\beta 3$ protein therapy of skin ulcers showed only modest benefits, ${ }^{170}$ and clinical experience with local TGF- $\beta$ therapies remains very limited. Moreover, local therapies carry the risk of excessive fibrosis and scar formation.

Another possible application is in the area of cardiovascular disease. TGF- $\beta$ regulates many of the events of the healing MI. This ranges from the early inflammatory response, to the late fibrotic response and the associated myocardial remodeling. There is also evidence that TGF- $\beta$ can protect cardiomyocytes from ischemic injury, as recently reviewed. ${ }^{148,171}$ However, limiting therapeutic intervention, 
there is the realization that TGF- $\beta$ has both positive and negative effects on the healing heart, ${ }^{102,148}$ and is a contributor to cardiac hypertrophy and vascular disease. It can be beneficial in atherosclerosis by stabilizing plaques, ${ }^{3,102,172}$ at least in animal models, but it also promotes vascular restenosis. Therefore, the appropriate timing of either TGF- $\beta$ or anti-TGF- $\beta$ therapy would be critical, and much more research is required in this area.

Returning to autoimmune diseases, an alternative approach to TGF- $\beta$ therapy is the induction of $\operatorname{Tr}$ cells that produce this cytokine. Experimentally, this has been achieved by induction of oral tolerance, ${ }^{48,49}$ but in human disease this approach has met with limited success. However, there is early evidence that some drugs can induce differentiation of TGF- $\beta$-producing $\operatorname{Tr}$ cells, and this might be an avenue for therapy. Furthermore, we have shown that DNA vaccination can be applied to the generation of these $\mathrm{Tr}$ cells. ${ }^{173}$ In our experiments, an autoantigen gene was co-delivered with a selective CTLA-4 ligand (mutated B7-1). This led to the generation of Foxp $3^{+}$Tr cells that appear to act by producing TGF- $\beta$. CTLA- 4 might act by priming the T cell for responsiveness to TGF- $\beta$ and subsequent Foxp3 induction. Other vaccination approaches to induce TGF- $\beta$-producing cells are also feasible. ${ }^{174}$ In addition, the systemic administration of CD3 mAb leads to the generation of TGF- $\beta$-producing $\operatorname{Tr}$ cells and protects mice against autoimmune diabetes, and this might be clinically applicable. ${ }^{175}$ In all these cases, the advantage is that $\operatorname{Tr}$ cells are generally antigen specific, and can home in to the target tissues and, presumably, exert a local effect rather than a systemic effect.

\section{CONCLUSIONS AND FUTURE PROSPECTS}

In this review, the author has demonstrated the pleiotropic activity of TGF- $\beta$ in a number of physiological and pathological processes. This cytokine contributes importantly to healing, immunoregulation and cancer progression. These effects are highly context dependent, and can be either beneficial or detrimental. However, a large number of diseases (including cancer) are characterized, at least at some phases, by TGF- $\beta$ overproduction and are amenable to anti-TGF- $\beta$ therapy. This can be accomplished by several methods, including antibodies, soluble receptors, receptor kinase antagonist drugs, antisense ODNs and a number of less specific drugs that are in widespread or limited clinical use, such as AngII antagonists and tranilast.

In view of TGF- $\beta$ 's numerous functions, and potent antiinflammatory effects, it might be assumed that its neutralization would be detrimental, or even fatal, but this has not proven to be the case. Indeed, relatively mild toxicity has been noted, but some adverse effects have been reported, and long-term safety remains to be established. Notably, AngII antagonists have few adverse effects, but the degree to which they inhibit TGF- $\beta$ in humans requires further analysis. On the other hand, the direct administration of TGF- $\beta$ for therapeutic purposes is more limited. This is due to toxicity and safety concerns, but local administration appears feasible, especially to promote wound healing.

Finally, the immunomodulatory effects of this cytokine are critically important, and the realization that it plays a key role in Tr-cell differentiation and survival is of major clinical interest. Drug therapy or vaccination therapy altering TGF- $\beta$ production and $\operatorname{Tr}$ differentiation might be applied to the treatment of autoimmune diseases, transplant rejection and various inflammatory conditions. However, in this case as well, TGF- $\beta$ 's dual personality raises the concern that it could also induce the differentiation of inflammatory Th17 $\mathrm{T}$ cells, and actually aggravate some autoimmune/inflammatory diseases. Undoubtedly, future studies will yield valuable data about all these therapies.

\section{ACKNOWLEDGEMENT}

The author's studies were funded by the Juvenile Diabetes Foundation International, the Canadian Diabetes Association, the Ontario Institute for Cancer Research, the Krembil Foundation (Toronto, Canada), the Li Ka Shing Knowledge Institute and Keenan Research Centre of St Michael's Hospital (Toronto), and the National Cancer Institute of Canada.

1. Flanders KC, Roberts AB. TGF $\beta$. In: Oppenheim JJ, Feldmann M (eds). Cytokine Reference, Vol. 1. Academic Press: San Diego, CA, 2001, pp 719-746.

2. Howe PH. Transforming growth factor $\beta$. In: Thompson AW, Lotze MT (eds). The Cytokine Handbook, 4th edn. Academic Press: San Diego, CA, 2003, pp 1119-1152.

3. Li MO, Wan YY, Sanjabi S, et al. Transforming growth factor-beta regulation of immune responses. Annu Rev Immunol 2006;24:99-146.

4. Hyytiainen $M$, Penttinen $C$, Keski-Oja J. Latent TGF-beta binding proteins: extracellular matrix association and roles in TGF-beta activation. Crit Rev Clin Lab Sci 2004;4:233-264.

5. Fox SW, Lovibond AC. Current insights into the role of transforming growth factor-beta in bone resorption. Mol Cell Endocrinol 2005;243:19-26.

6. Rubtsov YP, Rudensky AY. TGFbeta signalling in control of T-cellmediated self-reactivity. Nat Rev Immunol 2007;7:443-453.

7. Kallapur S, Shull M, Doetchman T. Phenotypes of TGFbeta knockout mice. In: Durum SK, Muegge K (eds). Cytokine Knockouts. Humana Press: Totowa, NJ, 1998, pp 335-368.

8. Kulkarni $A B$, Letterio JJ. The transforming growth factor beta-1 mouse: the phenotype and its implications for TGFbeta1 function. In: Durum SK, Muegge K (eds). Cytokine Knockouts. Humana Press: Totowa, NJ, 1998, pp 369-400.

9. Wahl SM. Transforming growth factor-beta: innately bipolar. Curr Opin Immunol 2007;19:55-62.

10. Weaver CT, Hatton RD, Mangan PR, et al. IL-17 family cytokines and the expanding diversity of effector T cell lineages. Annu Rev Immunol 2007:25:821-852.

11. Godar S, Horejsi V, Weidle UH, et al. M6P/IGFII-receptor complexes urokinase receptor and plasminogen for activation of transforming growth factor-beta1. Eur J Immunol 1999;29:1004-1013.

12. Munger JS, Huang $X$, Kawakatsu $H$, et al. The integrin alpha v beta 6 binds and activates latent TGF beta 1: a mechanism for regulating pulmonary inflammation and fibrosis. Cell 1999;96:319-328.

13. Schultz-Cherry S, Ribeiro S, Gentry L, et al. Thrombospondin binds and activates the small and large forms of latent transforming growth factor-beta in a chemically defined system. J Biol Chem 1994;269:26775-26782.

14. Ribeiro SM, Poczatek M, Schultz-Cherry $S$, et al. The activation sequence of thrombospondin-1 interacts with the latency-associated peptide to regulate activation of latent transforming growth factorbeta. J Biol Chem 1999;274:13586-13593.

15. Yu Q, Stamenkovic I. Cell surface-localized matrix metalloproteinase-9 proteolytically activates TGF-beta and promotes tumor invasion and angiogenesis. Genes Dev 2000;14:163-176. 
16. Yu Q, Stamenkovic I. Transforming growth factor-beta facilitates breast carcinoma metastasis by promoting tumor cell survival. Clin Exp Metastasis 2004;2:235-242.

17. Todorovic V, Jurukovski V, Chen Y, et al. Latent TGF-beta binding proteins. Int J Biochem Cell Biol 2005;37:38-41.

18. Abdalla SA, Letarte $M$. Hereditary haemorrhagic telangiectasia: current views on genetics and mechanisms of disease. J Med Genet 2006;43:97-110.

19. Lebrin F, Goumans MJ, Jonker L, et al. Endoglin promotes endothelial cell proliferation and TGF-beta/ALK1 signal transduction. EMBO J 2004;23:4018-4028.

20. Staton C, Kumar I, Reed M, et al. Neuropilins in physiological and pathological angiogenesis. J Pathol 2007;212:237-248.

21. Tordjman R, Lepelletier $Y$, Lemarchandel V, et al. A neuronal receptor, neuropilin-1, is essential for the initiation of the primary immune response. Nat Immunol 2002;3:477-482.

22. Bruder $D$, Probst-Kepper $M$, Westendorf AM, et al. Neuropilin-1: a surface marker of regulatory T cells. Eur J Immunol 2004;34:623-630.

23. O'Connor-McCourt MD, Wakefield LM. Latent transforming growth factor-beta in serum. A specific complex with alpha 2-macroglobulin. J Biol Chem 1987;262:14090-14099.

24. Prud'homme GJ, Piccirillo CA. The inhibitory effects of transforming growth factor-beta-1 (TGF-beta1) in autoimmune diseases. J Autoimmun 2000;14:23-42.

25. Fainaru O, Shay T, Hantisteanu S, et al. TGFbeta-dependent gene expression profile during maturation of dendritic cells. Genes Immun 2007;8:239-244.

26. Wahl SM, Hunt DA, Wakefield LM, et al. Transforming growth factor type beta induces monocyte chemotaxis and growth factor production. Proc Natl Acad Sci USA 1987;84:5788-5792.

27. Reibman J, Meixler S, Lee TC, et al. Transforming growth factor beta 1, a potent chemoattractant for human neutrophils, bypasses classic signaltransduction pathways. Proc Natl Acad Sci USA 1991;88:6805-6809.

28. Bettelli E, Carrier Y, Gao W, et al. Reciprocal developmental pathways for the generation of pathogenic effector TH17 and regulatory T cells. Nature 2006;441:235-238.

29. Yoshimura T, Takeda A, Hamano S, et al. Two-sided roles of IL-27: induction of Th1 differentiation on naive CD4+ T cells vs suppression of proinflammatory cytokine production including IL-23-induced IL-17 on activated CD4+ T cells partially through STAT3-dependent mechanism. J Immunol 2006;177:5377-5385.

30. Laurence A, Tato CM, Davidson TS, et al. Interleukin-2 signaling via STAT5 constrains T helper 17 cell generation. Immunity 2007;26: 371-381.

31. Nakae $\mathrm{S}$, Iwakura $\mathrm{Y}$, Suto $\mathrm{H}$, et al. Phenotypic differences between Th1 and Th17 cells and negative regulation of Th1 cell differentiation by IL-17. J Leukoc Biol 2007;81:1258-1268.

32. Xu L, Kitani A, Fuss I, et al. Cutting edge: regulatory $T$ cells induce CD4+CD25-Foxp3- T cells or are self-induced to become Th17 Cells in the absence of exogenous TGF-beta. J Immunol 2007;178: 6725-6729.

33. Lebman DA, Edmiston JS. The role of TGF-beta in growth differentiation, and maturation of B lymphocytes. Microbes Infect 1999;1:1297-1304.

34. Borsutzky S, Cazac BB, Roes J, et al. TGF-beta receptor signaling is critical for mucosal IgA responses. J Immunol 2004;173:3305-3309.

35. Shull MM, Ormsby I, Kier AB, et al. Targeted disruption of the mouse transforming growth factor-beta 1 gene results in multifocal inflammatory disease. Nature 1992;359:693-699.

36. Geiser AG, Letterio JJ, Kulkarni AB, et al. Transforming growth factor beta 1 (TGF-beta 1) controls expression of major histocompatibility genes in the postnatal mouse: aberrant histocompatibility antigen expression in the pathogenesis of the TGF-beta 1 null mouse phenotype. Proc Natl Acad Sci USA 1993;90:9944-9948.

37. Letterio JJ, Roberts AB. Regulation of immune responses by TGF-beta. Annu Rev Immunol 1998;16:137-161.

38. Li MO, Sanjabi S, Flavell RA. Transforming growth factor-beta controls development, homeostasis, and tolerance of $\mathrm{T}$ cells by regulatory $\mathrm{T}$ cell-dependent and -independent mechanisms. Immunity 2006;25:455-471.

39. Li MO, Wan YY, Flavell RA. T cell-produced transforming growth factor-beta 1 controls $T$ cell tolerance and regulates Th1- and Th17cell differentiation. Immunity 2007;26:579-591.
40. Wahl SM, Wen J, Moutsopoulos N. TGF-beta: a mobile purveyor of immune privilege. Immunol Rev 2006;213:213-227.

41. Levings MK, Allan S, d'Hennezel $E$, et al. Functional dynamics of naturally occurring regulatory $T$ cells in health and autoimmunity. Adv Immunol 2006;92:119-155.

42. Zheng SG, Wang J, Wang P, et al. IL-2 is essential for TGF-beta to convert naive CD4+CD25- cells to CD25+Foxp3+ regulatory T cells and for expansion of these cells. J Immunol 2007;178:2018-2027.

43. Marie JC, Letterio JJ, Gavin M, et al. TGF-beta1 maintains suppressor function and Foxp3 expression in CD4+CD25+ regulatory T cells. J Exp Med 2005;201:1061-1067.

44. Pyzik M, Piccirillo CA. TGF-beta-1 modulates Foxp3 expression and regulatory activity in distinct CD4+ T cell subsets. J Leukoc Biol 2007;82:335-346.

45. Selvaraj RK, Geiger TL. A kinetic and dynamic analysis of Foxp3 induced in T cells by TGF-beta. J Immunol 2007;178:7667-7677.

46. Oida $\mathrm{T}, \mathrm{Xu} \mathrm{L}$, Weiner $\mathrm{HL}$, et al. TGF-beta-mediated suppression by CD4+CD25+ T cells is facilitated by CTLA-4 signaling. J Immunol 2006;177:2331-2339.

47. Fahlen $L$, Read $S$, Gorelik $L$, et al. T cells that cannot respond to TGFbeta escape control by CD4(+)CD25(+) regulatory T cells. J Exp Med 2005;201:737-746.

48. Faria AM, Weiner HL. Oral tolerance: therapeutic implications for autoimmune diseases. Clin Dev Immunol 2006;13:143-157.

49. Faria AM, Weiner HL. Oral tolerance. Immunol Rev 2005;206:232-259.

50. Roncarolo MG, Gregori S, Battaglia M, et al. Interleukin-10-secreting type 1 regulatory T cells in rodents and humans. Immunol Rev 2006;212:28-50.

51. Werner S, Krieg T, Smola H. Keratinocyte-fibroblast interactions in wound healing. J Invest Dermatol 2007;127:998-1008.

52. Frangogiannis NG. Targeting the inflammatory response in healing myocardial infarcts. Curr Med Chem 2006;13:1877-1893.

53. Ruiz-Ortega M, Rodriguez-Vita J, Sanchez-Lopez E, et al. TGF-beta signaling in vascular fibrosis. Cardiovasc Res 2007;74:196-206.

54. Leask A. TGFbeta, cardiac fibroblasts, and the fibrotic response. Cardiovasc Res 2007;74:207-212.

55. Leask A. Scar wars: is TGFbeta the phantom menace in scleroderma? Arthritis Res Ther 2006;8:213-219.

56. Cutroneo KR, White SL, Phan $\mathrm{SH}$, et al. Therapies for bleomycin induced lung fibrosis through regulation of TGF-beta1 induced collagen gene expression. Cell Physiol 2007;211:585-589.

57. Gauldie J, Kolb M, Ask K, et al. Smad3 signaling involved in pulmonary fibrosis and emphysema. Proc Am Thorac Soc 2006;3:696-702.

58. Bottinger EP, Jakubczak JL, Haines DC, et al. Transgenic mice overexpressing a dominant-negative mutant type II transforming growth factor beta receptor show enhanced tumorigenesis in the mammary gland and lung in response to the carcinogen 7, 12dimethylbenz-[a]-anthracene. Cancer Res 1997;57:5564-5570.

59. Forrester E, Chytil A, Bierie B, et al. Effect of conditional knockout of the type II TGF-beta receptor gene in mammary epithelia on mammary gland development and polyomavirus middle T antigen induced tumor formation and metastasis. Cancer Res 2005;65:2296-2302.

60. Tian F, Byfield SD, Parks WT, et al. Smad-binding defective mutant of transforming growth factor beta type I receptor enhances tumorigenesis but suppresses metastasis of breast cancer cell lines. Cancer Res 2004;64:4523-4530.

61. Wakefield LM, Roberts AB. TGF-beta signaling: positive and negative effects on tumorigenesis. Curr Opin Genet Dev 2002;12:22-29.

62. Siegel PM, Massague J. Cytostatic and apoptotic actions of TGF-beta in homeostasis and cancer. Nat Rev Cancer 2003;3:807-821.

63. Galliher AJ, Neil JR, Schiemann WP. Role of transforming growth factor-beta in cancer progression. Future Oncol 2006;2:743-763.

64. Jakowlew SB. Transforming growth factor-beta in cancer and metastasis. Cancer Metastasis Rev 2006;25:435-457.

65. Stover DG, Bierie B, Moses HL. A delicate balance: TGF-beta and the tumor microenvironment. J Cell Biochem 2007;101:851-861.

66. Dong $M$, How $T$, Kirkbride $K C$, et al. The type III TGF-beta receptor suppresses breast cancer progression. J Clin Invest 2007;117:206-217.

67. Zavadil J, Bottinger E. TGF-beta and epithelial-to-mesenchymal transitions. Oncogene 2005;24:5764-5774.

68. Han G, Lu SL, Li AG, et al. Distinct mechanisms of TGF-beta1-mediated epithelial-to-mesenchymal transition and metastasis during skin carcinogenesis. J Clin Invest 2005;115:1714-1723. 
69. Muraoka RS, Koh Y, Roebuck LR, et al. Increased malignancy of Neu-induced mammary tumors overexpressing active transforming growth factor beta1. Mol Cell Biol 2003;23:8691-8703.

70. Oft $M$, Heider $\mathrm{KH}$, Beug $\mathrm{H}$. TGFbeta signaling is necessary for carcinoma cell invasiveness and metastasis. Curr Biol 1998;8:1243-1252.

71. Biswas S, Guix M, Rinehart C, et al. Inhibition of TGF-beta with neutralizing antibodies prevents radiation-induced acceleration of metastatic cancer progression. J Clin Invest 2007;117:1305-1313.

72. Arteaga $\mathrm{CL}$, Hurd $\mathrm{SD}$, Winnier $\mathrm{AR}$, et al. Anti-transforming growth factor (TGF)-beta antibodies inhibit breast cancer cell tumorigenicity and increase mouse spleen natural killer cell activity. Implications for a possible role of tumor cell/host TGF-beta interactions in human breast cancer progression. J Clin Invest 1993;92:2569-2576.

73. Saunier EF, Akhurst RJ. TGF beta inhibition for cancer therapy. Curr Cancer Drug Targets 2006;6:565-578.

74. Pinkas J, Teicher BA. TGF-beta in cancer and as a therapeutic target. Biochem Pharmacol 2006;72:523-529.

75. Ivanovic V, Demajo M, Krtolica K, et al. Elevated plasma TGF-beta1 levels correlate with decreased survival of metastatic breast cancer patients. Clin Chim Acta 2006;371:191-193.

76. Feltl D, Zavadova E, Pala M, et al. Post-treatment plasma transforming growth factor beta 1 (TGF-beta1) level predicts for late morbidity in patients with advanced head and neck cancer. Neoplasma 2005;52:393-397.

77. Fukuchi M, Miyazaki T, Fukai $Y$, et al. Plasma level of transforming growth factor beta1 measured from the azygos vein predicts prognosis in patients with esophageal cancer. Clin Cancer Res 2004;10:2738-2741.

78. Tsushima $\mathrm{H}$, Ito $\mathrm{N}$, Tamura $\mathrm{S}$, et al. Circulating transforming growth factor beta 1 as a predictor of liver metastasis after resection in colorectal cancer. Clin Cancer Res 2001;7:1258-1262.

79. Sinnreich O, Kratzsch J, Reichenbach A, et al. Plasma levels of transforming growth factor-1 beta and alpha2-macroglobulin before and after radical prostatectomy: association to clinicopathological parameters. Prostate 2004;61:201-208.

80. Gary Lee YC, Melkerneker D, Thompson PJ, et al. Transforming growth factor beta induces vascular endothelial growth factor elaboration from pleural mesothelial cells in vivo and in vitro. Am J Respir Crit Care Med 2002;165:88-94.

81. Benckert C, Jonas S, Cramer T, et al. Transforming growth factor beta 1 stimulates vascular endothelial growth factor gene transcription in human cholangiocellular carcinoma cells. Cancer Res 2003;63:1083-1092.

82. Serafini P, Borrello I, Bronte V. Myeloid suppressor cells in cancer: recruitment, phenotype, properties, and mechanisms of immune suppression. Semin Cancer Biol 2006;16:53-65.

83. Kobie JJ, Wu RS, Kurt RA, et al. Transforming growth factor beta inhibits the antigen-presenting functions and antitumor activity of dendritic cell vaccines. Cancer Res 2003:63:1860-1864.

84. Chen ML, Pittet MJ, Gorelik L, et al. Regulatory T cells suppress tumorspecific CD8 T cell cytotoxicity through TGF-beta signals in vivo. Proc Natl Acad Sci USA 2005;102:419-424.

85. Kang $\mathrm{Y}, \mathrm{He} \mathrm{W}$, Tulley $\mathrm{S}$, et al. Breast cancer bone metastasis mediated by the Smad tumor suppressor pathway. Proc Natl Acad Sci USA 2005;102:13909-13914.

86. Kang $Y$, Siegel PM, Shu W, et al. A multigenic program mediating breast cancer metastasis to bone. Cancer Cell 2003;3:537-549.

87. Yin JJ, Selander K, Chirgwin JM, et al. TGF-beta signaling blockade inhibits PTHrP secretion by breast cancer cells and bone metastases development. J Clin Invest 1999;103:197-206.

88. Rose AA, Siegel PM. Breast cancer-derived factors facilitate osteolytic bone metastasis. Bull Cancer 2006;93:931-943.

89. Guise TA, Chirgwin JM. Transforming growth factor-beta in osteolytic breast cancer bone metastases. Clin Orthop Relat Res 2003; (415 Suppl):S32-S38.

90. Bandyopadhyay A, Agyin JK, Wang L, et al. Inhibition of pulmonary and skeletal metastasis by a transforming growth factor-beta type I receptor kinase inhibitor. Cancer Res 2006;66:6714-6721.

91. Kakonen SM, Selander KS, Chirgwin JM, et al. Transforming growth factor-beta stimulates parathyroid hormone-related protein and osteolytic metastases via Smad and mitogen-activated protein kinase signaling pathways. J Biol Chem 2002;277:24571-24578.
92. Lahn M, Kloeker S, Berry BS. TGF-beta inhibitors for the treatment of cancer. Expert Opin Investig Drugs 2005;14:629-643.

93. Akhurst RJ. Large- and small-molecule inhibitors of transforming growth factor-beta signaling. Curr Opin Investig Drugs 2006;7: 513-521.

94. Tsuchida K, Sunada Y, Noji S, et al. Inhibitors of the TGF-beta superfamily and their clinical applications. Mini Rev Med Chem 2006;6:1255-1261.

95. de Gouville AC, Huet S. Inhibition of ALK5 as a new approach to treat liver fibrotic diseases. Drug News Perspect 2006;19:85-90.

96. Liu X, Hu H, Yin JQ. Therapeutic strategies against TGF-beta signaling pathway in hepatic fibrosis. Liver Int 2006;26:8-22.

97. Wick W, Naumann U, Weller M. Transforming growth factor-beta: a molecular target for the future therapy of glioblastoma. Curr Pharm Des 2006;12:341-349.

98. Breitkopf $\mathrm{K}$, Haas $\mathrm{S}$, Wiercinska $\mathrm{E}$, et al. Anti-TGF-beta strategies for the treatment of chronic liver disease. Alcohol Clin Exp Res 2005;29(11 Suppl):121S-131S.

99. Burke JP, Mulsow JJ, O'Keane C, et al. Fibrogenesis in Crohn's disease. Am J Gastroenterol 2007;102:439-448.

100. Lim H, Zhu YZ. Role of transforming growth factor-beta in the progression of heart failure. Cell Mol Life Sci 2006;63:2584-2596.

101. Cutroneo KR, White SL, Phan SH, et al. for bleomycin induced lung fibrosis through regulation of TGF-beta1 induced collagen gene expression. J Cell Physiol 2007;211:585-589.

102. Dabek J, Kulach A, Monastyrska-Cup B, et al. Transforming growth factor beta and cardiovascular diseases: the other facet of the 'protective cytokine'. Pharmacol Rep 2006;58:799-805.

103. Wojtowicz-Praga S. Reversal of tumor-induced immunosuppression by TGF-beta inhibitors. Invest New Drugs 2003;2:21-32.

104. Ruzek MC, Hawes $M$, Pratt $B$, et al. Minimal effects on immune parameters following chronic anti-TGF-beta monoclonal antibody administration to normal mice. Immunopharmacol Immunotoxicol 2003;25:235-257.

105. Yang YA, Dukhanina O, Tang B, et al. Lifetime exposure to a soluble TGF-beta antagonist protects mice against metastasis without adverse side effects. J Clin Invest 2002;109:1607-1615.

106. Santiago B, Gutierrez-Canas I, Dotor J, et al. Topical application of a peptide inhibitor of transforming growth factor-beta1 ameliorates bleomycin-induced skin fibrosis. J Invest Dermatol 2005;125:450-455.

107. Vilchis-Landeros MM, Montiel JL, Mendoza V, et al. Recombinant soluble betaglycan is a potent and isoform-selective transforming growth factor-beta neutralizing agent. Biochem J 2001;355(Part 1):215-222.

108. Bandyopadhyay A, Lopez-Casillas F, Malik SN, et al. Antitumor activity of a recombinant soluble betaglycan in human breast cancer xenograft. Cancer Res 2002;62:4690-4695.

109. Bonniaud P, Margetts PJ, Kolb M, et al. Progressive transforming growth factor beta1-induced lung fibrosis is blocked by an orally active ALK5 kinase inhibitor. Am J Respir Crit Care Med 2005;171: 889-898.

110. Konneh M. Tranilast, Kissei Pharmaceuticals. Idrugs 1998;1:141-146.

111. Pfab T, Hocher B. Tranilast and hypertensive heart disease: further insights into mechanisms of an anti-inflammatory and anti-fibrotic drug. J Hypertens 2004;22:883-886.

112. Koda $A$, Kurashina $Y$, Nakazawa $M$. The inhibition mechanism of histamine release by $\mathrm{N}$-(3,4-dimethoxycinnamoyl) anthranilic acid. Int Arch Allergy Appl Immunol 1985;77:244-245.

113. Shioda H. A double blind controlled trial of $\mathrm{N}-\left(3^{\prime}, 4^{\prime}\right.$ dimethoxycinnamoyl) anthranilic acid on children with bronchial asthma. N-5' Study Group in Children. Allergy 1979;34:213-219.

114. Okuda M, Ishikawa $\mathrm{T}$, Saito $\mathrm{Y}$, et al. A clinical evaluation of $\mathrm{N}-5^{\prime}$ with perennial-type allergic rhinitis - a test by the multi-clinic, intergroup, double-blind comparative method. Ann Allergy 1984;53:178-185.

115. Suzawa $\mathrm{H}$, Kikuchi $\mathrm{S}$, Arai $\mathrm{N}$, et al. The mechanism involved in the inhibitory action of tranilast on collagen biosynthesis of keloid fibroblasts. Jpn J Pharmacol 1992;60:91-96.

116. Suzawa H, Kikuchi S, Ichikawa K, et al. Effect of tranilast, an antiallergic drug, on the human keloid tissues. Nippon Yakurigaku Zasshi 1992;99:231-239.

117. Yamada H, Tajima S, Nishikawa T, et al. Tranilast, a selective inhibitor of collagen synthesis in human skin fibroblasts. J Biochem (Tokyo) 1994;116:892-897. 
118. Mori $\mathrm{H}$, Kawada $\mathrm{K}$, Zhang $\mathrm{P}$, et al. Bleomycin-induced pulmonary fibrosis in genetically mast cell-deficient WBB6F1-W/Wv mice and mechanism of the suppressive effect of tranilast, an antiallergic drug inhibiting mediator release from mast cells, on fibrosis. Int Arch Allergy Appl Immunol 1991;95:195-201.

119. Isaji M, Aruga N, Naito J, et al. Inhibition by tranilast of collagen accumulation in hypersensitive granulomatous inflammation in vivo and of morphological changes and functions of fibroblasts in vitro. Life Sci 1994;55:PL287-PL292.

120. Mori $\mathrm{H}$, Tanaka $\mathrm{H}$, Kawada $\mathrm{K}$, et al. Suppressive effects of tranilast on pulmonary fibrosis and activation of alveolar macrophages in mice treated with bleomycin: role of alveolar macrophages in the fibrosis. Jpn J Pharmacol 1995;67:279-289.

121. Pinto YM, Pinto-Sietsma SJ, Philipp $T$, et al. Reduction in left ventricular messenger RNA for transforming growth factor beta(1) attenuates left ventricular fibrosis and improves survival without lowering blood pressure in the hypertensive TGR(mRen2)27 Rat. Hypertension 2000;36:747-754.

122. Hocher B, Godes M, Olivier J, et al. Inhibition of left ventricular fibrosis by tranilast in rats with renovascular hypertension. J Hypertens 2002;20:745-751.

123. Kagitani $\mathrm{S}$, Ueno $\mathrm{H}$, Hirade $\mathrm{S}$, et al. Tranilast attenuates myocardial fibrosis in association with suppression of monocyte/macrophage infiltration in DOCA/salt hypertensive rats. J Hypertens 2004;22:10071015.

124. Jones SE, Gilbert RE, Kelly DJ. Tranilast reduces mesenteric vascular collagen deposition and chymase-positive mast cells in experimental diabetes. J Diabetes Complicat 2004;18:309-315.

125. Martin J, Kelly DJ, Mifsud SA, et al. Tranilast attenuates cardiac matrix deposition in experimental diabetes: role of transforming growth factor-beta. Cardiovasc Res 2005;65:694-701.

126. Xu Q, Norman JT, Shrivastav $\mathrm{S}$, et al. In vitro models of TGF-betainduced fibrosis suitable for high-throughput screening of antifibrotic agents. Am J Physiol Renal Physiol 2007;293:F631-F640.

127. Miyazawa K, Kikuchi S, Fukuyama J, et al. Inhibition of PDGF- and TGFbeta 1-induced collagen synthesis, migration and proliferation by tranilast in vascular smooth muscle cells from spontaneously hypertensive rats. Atherosclerosis 1995;118:213-221.

128. Ikeda $\mathrm{H}$, Inao $\mathrm{M}$, Fujiwara $\mathrm{K}$. Inhibitory effect of tranilast on activation and transforming growth factor beta 1 expression in cultured rat stellate cells. Biochem Biophys Res Commun 1996;227:322-327.

129. Ward MR, Sasahara T, Agrotis A, et al. Inhibitory effects of tranilast on expression of transforming growth factor-beta isoforms and receptors in injured arteries. Atherosclerosis 1998;137:267-275.

130. Ward MR, Agrotis A, Kanellakis P, et al. Tranilast prevents activation of transforming growth factor-beta system, leukocyte accumulation, and neointimal growth in porcine coronary arteries after stenting. Arterioscler Thromb Vasc Biol 2002;22:940-948.

131. Platten $M$, Wild-Bode C, Wick W, et al. N-[3,4-dimethoxycinnamoyl]anthranilic acid (tranilast) inhibits transforming growth factor-beta relesase and reduces migration and invasiveness of human malignant glioma cells. Int J Cancer 2001;193:53-61.

132. Capper EA, Roshak AK, Bolognese BJ, et al. Modulation of human monocyte activities by tranilast, SB 252218, a compound demonstrating efficacy in restenosis. J Pharmacol Exp The 2000;295:1061-1069.

133. Bonnet F, Cao Z, Cooper ME, et al. Tranilast attenuates vascular hypertrophy, matrix accumulation and growth factor overexpression in experimental diabetes. Diabetes Metab 2003;29(4 Part 1):386-392.

134. Yashiro M, Murahashi K, Matsuoka T, et al. Tranilast $(\mathrm{N}-3,4$ dimethoxycinamoyl anthranilic acid): a novel inhibitor of invasionstimulating interaction between gastric cancer cells and orthotopic fibroblasts. Anticancer Res 2003;23(5A):3899-3904.

135. Mifsud S, Kelly DJ, Qi W, et al. Intervention with tranilast attenuates renal pathology and albuminuria in advanced experimental diabetic nephropathy. Nephron Physiol 2003;95:p83-p91.

136. Kelly DJ, Zhang $Y$, Gow $R$, et al. Tranilast attenuates structural and functional aspects of renal injury in the remnant kidney model. J Am Soc Nephrol 2004;15:2619-2629.

137. Akahori H, Ota T, Torita M, et al. Tranilast prevents the progression of experimental diabetic nephropathy through suppression of enhanced extracellular matrix gene expression. J Pharmacol Exp Ther 2005;314:514-521.
138. Qi W, Chen X, Twigg S, et al. Tranilast attenuates connective tissue growth factor-induced extracellular matrix accumulation in renal cells. Kidney Int 2006;69:989-995.

139. Kelly DJ, Zhang Y, Cox AJ, et al. Combination therapy with tranilast and angiotensin-converting enzyme inhibition provides additional renoprotection in the remnant kidney model. Kidney Int 2006;69:1954-1960.

140. Platten M, Ho PP, Youssef $S$, et al. Treatment of autoimmune neuroinflammation with a synthetic tryptophan metabolite. Science 2005;310:850-855.

141. Chikaraishi A, Hirahashi J, Takase O, et al. Tranilast inhibits interleukin1 beta-induced monocyte chemoattractant protein-1 expression in rat mesangial cells. Eur J Pharmacol 2001;427:151-158.

142. Isaji M, Miyata $\mathrm{H}$, Ajisawa $\mathrm{Y}$, et al. Inhibition by tranilast of vascular endothelial growth factor (VEGF)/vascular permeability factor (VPF)induced increase in vascular permeability in rats. Life Sci 1998;63:PL71-PL74.

143. Oshitani N, Yamagami H, Watanabe K, et al. Long-term prospective pilot study with tranilast for the prevention of stricture progression in patients with Crohn's disease. Gut 2007;56:599-600.

144. Nakajima K, Okita Y, Matsuda S. Sensitivity of scirrhous gastric cancer to 5 -fluorouracil and the role of cancer cell-stromal fibroblast interaction. Oncol Rep 2004;12:85-90.

145. Shime $H$, Kariya $M$, Orii $A$, et al. Tranilast inhibits the proliferation of uterine leiomyoma cells in vitro through $\mathrm{G} 1$ arrest associated with the induction of p21(waf1) and p53. J Clin Endocrinol Metab 2002;87:5610-5617.

146. Sata M, Takahashi A, Tanaka K, et al. Mouse genetic evidence that tranilast reduces smooth muscle cell hyperplasia via a p21(WAF1)-dependent pathway. Arterioscler Thromb Vasc Biol 2002;22:1305-1309.

147. Wolf $\mathrm{G}$. Renal injury due to renin-angiotensin-aldosterone system activation of the transforming growth factor-beta pathway. Kidney Int 2006;70:1914-1919.

148. Bujak $M$, Frangogiannis NG. The role of TGF-beta signaling in myocardial infarction and cardiac remodeling. Cardiovasc Res 2007;74:184-195.

149. Tox U, Steffen HM. Impact of inhibitors of the renin-angiotensinaldosterone system on liver fibrosis and portal hypertension. Curr Med Chem 2006;13:3649-3661.

150. Yao HW, Zhu JP, Zhao MH, et al. Losartan attenuates bleomycininduced pulmonary fibrosis in rats. Respiration 2006;73:236-242.

151. Cohn RD, van Erp C, Habashi JP, et al. Angiotensin II type 1 receptor blockade attenuates TGF-beta-induced failure of muscle regeneration in multiple myopathic states. Nat Med 2007;13:204-210.

152. Zhou Y, Poczatek MH, Berecek KH, et al. Thrombospondin 1 mediates angiotensin II induction of TGF-beta activation by cardiac and renal cells under both high and low glucose conditions. Biochem Biophys Res Commun 2006;339:633-641.

153. Dussaule JC, Chatziantoniou C. Reversal of renal disease: is it enough to inhibit the action of angiotensin II? Cell Death Differ 2007;14:1343-1349.

154. Redondo S, Santos-Gallego CG, Tejerina T. TGF-beta1: a novel target for cardiovascular pharmacology. Cytokine Growth Factor Rev 2007;18:279-286.

155. Kim Sl, Kim HJ, Han DC, et al. Effect of lovastatin on small GTP binding proteins and on TGF-beta1 and fibronectin expression. Kidney Int Suppl 2000;77:S88-S92.

156. Watts KL, Spiteri MA. Connective tissue growth factor expression and induction by transforming growth factor-beta is abrogated by simvastatin via a Rho signaling mechanism. Am J Physiol Lung Cell Mol Physiol 2004;287:L1323-L1332.

157. Vieira Jr JM, Mantovani E, Rodrigues LT, et al. Simvastatin attenuates renal inflammation, tubular transdifferentiation and interstitial fibrosis in rats with unilateral ureteral obstruction. Nephrol Dial Transplant 2005;20:1582-1591.

158. Antoniu SA. Pirfenidone for the treatment of idiopathic pulmonary fibrosis. Expert Opin Investig Drugs 2006;15:823-828.

159. Lasky J. Pirfenidone. IDrugs 2004;7:166-172.

160. Frazier K, Thomas R, Scicchitano M, et al. Inhibition of ALK5 signaling induces physeal dysplasia in rats. Toxicol Pathol 2007;35:284-295.

161. Hiroi $M$, Onda $M$, Uchida $E$, et al. Antitumor effect of $N-[3,4$ dimethoxycinnamoyl]-anthranilic acid (tranilast) on experimental pancreatic cancer. J Nippon Med Sch 2002;69:224-234. 
162. Murahashi $\mathrm{K}$, Yashiro $\mathrm{M}$, Inoue $\mathrm{T}$, et al. Tranilast and cisplatin as an experimental combination therapy for scirrhous gastric cancer. Int J Oncol 1998;13:1235-1240.

163. Noguchi N, Kawashiri S, Tanaka A, et al. Effects of fibroblast growth inhibitor on proliferation and metastasis of oral squamous cell carcinoma. Oral Oncol 2003;39:240-247.

164. Yatsunami J, Aoki S, Fukuno Y, et al. Antiangiogenic and antitumor effects of tranilast on mouse lung carcinoma cells. Int J Oncol 2000;17:1151-1156.

165. Mehta JL, Attramadal H. The TGFbeta superfamily in cardiovascular biology. Cardiovasc Res 2007;74:181-183.

166. Piccirillo CA, Prud'homme GJ. Immune modulation by plasmid DNAmediated cytokine gene transfer. Curr Pharm Des 2003;9:83-94.

167. Prud'homme GJ, Glinka Y, Khan AS, et al. Electroporation-enhanced nonviral gene transfer for the prevention or treatment of immunological, endocrine and neoplastic diseases. Curr Gene Ther 2006;6:243-273.

168. Terrell TG, Working PK, Chow CP, et al. Pathology of recombinant human transforming growth factor-beta 1 in rats and rabbits. Int Rev Exp Pathol 1993;34(Part B):43-67.
169. Lee PY, Chesnoy S, Huang L. Electroporatic delivery of TGF-beta1 gene works synergistically with electric therapy to enhance diabetic wound healing in db/db mice. J Invest Dermatol 2004;123:791-798.

170. Hirshberg J, Coleman J, Marchant B, et al. TGF-beta3 in the treatment of pressure ulcers: a preliminary report. Adv Skin Wound Care 2001;14:91-95.

171. Hermonat PL, Li D, Yang B, et al. Mechanism of action and delivery possibilities for TGFbeta1 in the treatment of myocardial ischemia. Cardiovasc Res 2007;74:235-243.

172. Grainger DJ. TGF-beta and atherosclerosis in man. Cardiovasc Res 2007;74:213-222.

173. Glinka Y, Chang Y, Prud'homme GJ. Protective regulatory $T$ cell generation in autoimmune diabetes by DNA covaccination with islet antigens and a selective CTLA-4 ligand. Mol Ther 2006;14:578-587.

174. Prud'homme GJ, Draghia-Akli R, Wang Q. Plasmid-based gene therapy of diabetes mellitus. Gene Ther 2007;14:553-564.

175. You S, Thieblemont N, Alyanakian MA, et al. Transforming growth factor-beta and T-cell-mediated immunoregulation in the control of autoimmune diabetes. Immunol Rev 2006;212:185-202. 